\title{
APLIKASI WEB PENGELOLAAN TUGAS AKHIR PADA TEKNIK INFORMATIKA STMIK PALANGKARAYA
}

\author{
Herkules ${ }^{1}$, Yogi Hapa ${ }^{2}$ \\ 1,2)Program Studi Teknik Informatika \\ Sekolah Tinggi Manajemen Informatika dan Komputer (STMIK) Palangkaraya \\ Jl. G.Obos No 114 Palangkaraya Kalimantan Tengah \\ Email: herkules@stmikplk.ac.id,Yogihapa@gmail.com
}

\begin{abstract}
The problem in this research is how to make Web Application for management Thesis data on Teknik Informatika STMIK Palangkaraya. The web application can help and simplify for students and officers can apply the title of research, seminar schedule submission, and final exam schedule submission.

The method used in this research include observation, interviews, literature and documentation. Software development method that used for creation flow system using methods developed software system development life cycle ( SDLC) with the waterfall model development approach. This research has been successfully implemented using Codeigniter Framework, MySQL and CSS framework Bootstrap and has been successfully tested with blaxbox testing. The web application can simplify and accelerate the management of data student's thesis on Teknik Informatika STMIK Palangkaraya.
\end{abstract}

Keyword :Application, Codeigniter, Framework PHP, Web Application.

\section{PENDAHULUAN}

Teknologi internet merupakan salah satu bidang yang mengalami perkembangan sangat cepat. Telah banyak sektor yang menerapkan teknologi ini, salah satunya dalam pengelolaan data akademik. Hal ini membawa kita dalam budaya baru dalam melakukan proses pengelolaan data yang tidak lagi konvensional yaitu dengan menggunakan mesin ketik atau catatan pada kertas, melainkan membawa kita kepada pengelolaan data yang bisa dilakukan dimana saja dan kapan saja. Menurut Jogianto 2005:231) Perangkat lunak aplikasi (application software), yaitu program yang ditulis dan diterjemahkan oleh language software untuk menyelesaikan suatu aplikasi tertentu, Aplikasi berasal dari kata application yang artinya penerapan,lamaran,penggunaan. Secara istilah aplikasi adalah: program siap pakai yang direkap untuk melaksanakan suatu fungsi bagi pengguna atau 
aplikasi yang lain dan dapat digunakan oleh sasaran yang dituju.

Seperti pada beberapa penelitian yang dilakukan oleh Kandaga dan Felix (2011), Universitas Kristen Maranatha mengenai pembuatan aplikasi pengelolaan tugas akhir online berbasis web studi kasus jurusan teknik informatika UKM, dan Primasetya (2013) mengenai aplikasi pengajuan skripsi mahasiswa jurusan sistem snformasi Universitas Gunadarma berbasis android, disadari atau tidak penerapan perangkat lunak atau aplikasi berbasis web dewasa ini telah berdampak pada kemudahan dalam penyampaian informasi. Berdasarkan hal itu STMIK Palangkaraya juga sudah menerapkan perangkat lunak pengelolaan data akademik berbasis web tetapi belum diterapkan pada pengelolaan data tugas akhir terutama di tingkat jurusan.

STMIK Palangkaraya terutama jurusan Teknik Informatika dalam pengelolaan tugas akhir masih menggunakan cara konvensional dengan menggunakan catatan atau buku besar dan Microsoft Word dan Excel dalam membuat laporan sehingga terkadang pengelolaan data menjadi kurang efektif dalam hal memantau data dan menyampaikan informasi mengenai judul tugas akhir mahasiswa.

Untuk meningkatkan layanan dan juga mempermudah tugas jurusan dalam mengelola data tugas akhir mahasiswa dengan mudah maka dikembangkan sebuah aplikasi berbasis web untuk mendukung kegiatan proses dari pengajuan judul, pengajuan jadwal seminar,pengajuan jadwal sidang tugas akhir hingga informasi daftar judul tugas akhir yang telah disetujui sehingga mahasiswa semester akhir semakin mudah mendapatkan informasi dan referensi mengenai judul tugas akhir yang telah ada di STMIK Palangkaraya.

Pada penelitian ini telah dikembangkan sebuah sistem aplikasi berbasis web yang dapat digunakan sebagai sarana untuk mempermudah pihak jurusan dalam mengelola data tugas akhir dan menyampaikan informasi yang terkait dengan tugas akhir mahasiswa dengan pendekatan pemrograman Berorientasi Objek (OOP). Menurut saputra (2012:15) Teknik pemrograman OOP bisa disebut juga sebagai teknik pemrograman modern yang menganggap segala sesuatu dalam bahasa pemrograman 
adalah objek, bahkan variabel pun dianggap sebagai suatu objek.

\section{METODE PENELITIAN}

Penelitian ini dilakukan mulai dari tahap pengumpulan data dengan memanfaatkan metode :

- Studi pustaka, pengumpulan data dengan cara mencari data-data yang diperlukan dari membaca dan mempelajari buku-buku yang berhubungan dengan pengelolaan data tugas akhir pada jurusan Teknik Informatika STMIK Palangkaraya.

- Observasi, yaitu dengan cara mengamati langsung ke objek penelitian pada STMIK Palangkaraya dalam hal ini penulis telah melakukan pengamatan mengenai pengelola data skripsi yang ada di STMIK palangkaraya.

- Wawancara (Interview), dengan cara melakukan wawancara atau interview secara langsung dengan petugas STMIK palangkaraya. Dalam hal ini penulis mengajukan pertanyaan kepada petugas dan melakukan Tanya jawab mengenai hal-hal yang berkaitan dengan kebutuhan penulisan dan pembuatan pengelola data skripsi nantinya.
- Dokumentasi, dengan mempelajari dokumen-dokumen yang digunakan dalam pengelolaan data tugas akhir seperti pedoman Tugas akhir.

Metode

Pengembangan Perangkat lunak yang digunakan dalam pembuatan aplikasi web pengelolaan tugas akhir di STMIK Palangkaraya adalah metode System Development Life Cycle (SDLC) dengan menggunakan pendekatan pengembangan model air terjun (waterfall) atau siklus hidup perangkat lunak.

1) Analisis Kebutuhan

Pada tahap ini yaitu analisa kebutuhan. Dalam menganalisa kebutuhan penulis meninjau langsung sistem yang berjalan di STMIK Palangkaraya, setelah menganalisa dan menemukan permasalahannya maka penulis menetapkan kebutuhankebutuhan apa saja yang akan digunakan pada sistem untuk membantu menyelesaikan permasalahan yang ada.

2) Desain Sistem dan Desain Program Dalam tahap ini penulis melakukan proses perancangan model sistem dan desain interface program agar alur dari proses program tersebut jelas, untuk pemodelan sistem penulis menggunakan pemodelan sistem Unified Modeling Language (UML). Menurut pressman 
(2010:987) Unified Modelling

Language merupakan bahasa standar untuk penulisan cetak biru perangkat lunak. UML dapat digunakan untuk memvisualisasikan, menentukan, mengonstruksi dan mendokumentasikan artifak-artifak suatu sistem softwareintensive.

Diagram UML yang di desain yaitu : Use case, class diagram, activity diagram,dan sequence diagram

3) Implementasi dan Testing

Tahap selanjutnya yaitu implementasi dan testing. Dalam tahap ini yang akan penulis lakukan adalah membuat aplikasi menggunakan bahasa pemrograman PHP. Setelah program selesai dibuat maka yang akan dilakukan penulis adalah testing dengan menggunakan black box testing, ini dilakukan untuk menguji jalannya aplikasi sudah sesuai dengan yang diharapkan atau belum. Testing dilakukan oleh Ketua Jurusan Teknik Informatika.

4) Integrasi dan Pengujian Sistem

Tahap yang keempat adalah Integrasi dan Pengujian Sistem. Dalam tahap ini yang penulis lakukan adalah menggabungkan unit-unit program dan mengujinya. Setelah di ujicoba dan hasilnya sudah sesuai dengan kebutuhan maka selanjutnya pengujian system. Untuk menguji system, yang akan dilakukan adalah menjalankan sistem di browser dengan pengoperasian yang dilakukan oleh user.

5) Pemeliharaan

Pada tahap yang terakhir adalah pemeliharaan. Dalam tahap ini aplikasi telah selesai dan dapat dikembangkan sesuai dengan permintaan user yaitu Dosen, dan Mahasiswa pada STMIK Palangkaraya.

\section{HASIL DAN PEMBAHASAN}

Analisa yang digunakan untuk menganalisa kelemahan sistem ini adalah metode PIECES. Dimana dengan menggunakan metode ini akan dilakukan analisis secara detail pada kinerja (performance), informasi (information), ekonomi (economic), kontrol (control), analisis efisiensi (efficiency) dan pelayanan (service) dari sistem. Hasil dari analisa terangkum pada tabel 1 dibawah ini : 
Tabel 1. Analisis PIECES

\begin{tabular}{|c|c|c|}
\hline PIECES & Sistem lama & Sistem Baru \\
\hline $\begin{array}{l}\text { Performance } \\
\text { (kinerja) }\end{array}$ & $\begin{array}{l}\text { Informasi } \\
\text { judul yang } \\
\text { telah disetujui } \\
\text { dan dosen } \\
\text { pembimbing di } \\
\text { informasikan } \\
\text { melalui papan } \\
\text { pengumuman }\end{array}$ & $\begin{array}{l}\text { pengajuan judul } \\
\text { serta Informasi } \\
\text { terkait Tugas } \\
\text { akhir dapat } \\
\text { diakses secara } \\
\text { online menjadi } \\
\text { lebih cepat dan } \\
\text { dapat diakses } \\
\text { kapan saja dan } \\
\text { di mana saja }\end{array}$ \\
\hline $\begin{array}{l}\text { Information } \\
\text { (Informasi) }\end{array}$ & $\begin{array}{l}\text { Informasi yang } \\
\text { disajikan } \\
\text { kurang } \\
\text { lengkap hanya } \\
\text { Judul dan } \\
\text { dosen } \\
\text { pembimbing }\end{array}$ & $\begin{array}{l}\text { sistem } \\
\text { mengolah } \\
\text { informasi yang } \\
\text { diinginkan } \\
\text { pengguna } \\
\text { seperti judul } \\
\text { skripsi yang } \\
\text { telah disetujui, } \\
\text { waktu } \\
\text { pelaksanaan } \\
\text { sidang, syarat } \\
\text { pengajuan yang } \\
\text { kurang. }\end{array}$ \\
\hline $\begin{array}{l}\text { Economic } \\
\text { (Ekonomi) }\end{array}$ & $\begin{array}{l}\text { Masih perlu } \\
\text { biaya } \\
\text { mencetak } \\
\text { proposal }\end{array}$ & Papperless \\
\hline $\begin{array}{l}\text { Control } \\
\text { (Kontrol) }\end{array}$ & $\begin{array}{l}\text { Input data } \\
\text { dilakukan } \\
\text { petugas } \\
\text { jurusan, } \\
\text { mengolah data } \\
\text { dan mencetak } \\
\text { kembali } \\
\text { informasi } \\
\text { untuk di } \\
\text { umumkan ke } \\
\text { mahasiswa } \\
\end{array}$ & $\begin{array}{l}\text { Input data } \\
\text { Proposal } \\
\text { dilakukan } \\
\text { mahasiswa, } \\
\text { operator lebih } \\
\text { mudah mendata } \\
\text { dan melaporkan } \\
\text { informasi } \\
\text { secara online } \\
\text { ke mahasiswa }\end{array}$ \\
\hline $\begin{array}{l}\text { Eficiency } \\
\text { (Efisiensi) }\end{array}$ & $\begin{array}{l}\text { Pengolahan } \\
\text { data Tugas } \\
\text { akhir } \\
\text { bertumpu pada } \\
\text { operator } \\
\text { jurusan } \\
\text { Sehingga } \\
\text { beban kerja } \\
\text { berat. } \\
\end{array}$ & $\begin{array}{l}\text { Data diolah } \\
\text { dengan cepat } \\
\text { dan akurat } \\
\text { dengan } \\
\text { pembagian user } \\
\text { mahasiswa dan } \\
\text { operator. }\end{array}$ \\
\hline $\begin{array}{l}\text { Service } \\
\text { (Pelayanan) }\end{array}$ & $\begin{array}{l}\text { Pelayanan } \\
\text { informasi lama } \\
\text { dan } \\
\text { membutuhkan } \\
\text { waktu tunggu } \\
\text { cukup lama } \\
\text { untuk } \\
\text { mahasiswa }\end{array}$ & $\begin{array}{l}\text { pengguna } \\
\text { hanya perlu } \\
\text { menjalankan } \\
\text { sistem untuk } \\
\text { informasi } \\
\text { mengenai judul } \\
\text { dan proses } \\
\text { pelaksanaan } \\
\text { seminar dan } \\
\text { sidang skripsi } \\
\text { sehingga }\end{array}$ \\
\hline
\end{tabular}

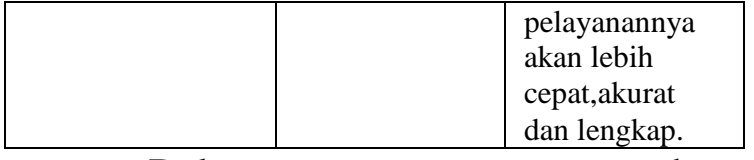

Dalam merancang proses pada aplikasi web pengelolaan data tugas akhir pada teknik informatika STMIK Palangkaraya, penulis membuat model Use Case Diagram,Class Diagram, sequence Diagram, dan Activity Diagram serta ER-D untuk menggambarkan tempat penyimpanan data.

\section{Use Case Diagram}

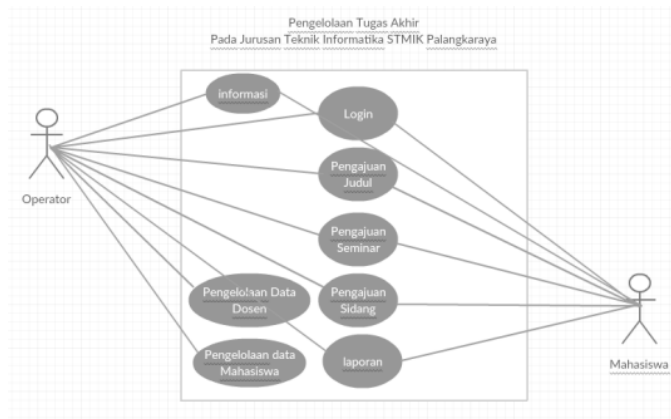

Gambar 2. Usecase Diagram

\section{Pada Gambar 2 Usecase} diagram Diagram terdapat 2 aktor yaitu admin, dan mahasiswa. Admin dapat melakukan login terlebih dahulu untuk dapat mengelola data mahasiswa, dosen, data pengajuan judul oleh mahasiswa, ,jadwal seminar dan jadwal sidang tugas akhir dan laporan terkait data Judul, Seminar dan Sidang Akhir mahasiswa. Setelah admin selesai mengelola sistem input maka akan menghasilkan output berupa informasi yang dapat dilihat oleh mahasiswa seperti status judul,jadwal seminar dan jadwal sidang. Di sistem mahasiswa dapat melakukan akses ke 
website untuk melihat daftar Judul,jadwal seminar,dan jadwal Sidang Tugas akhir serta melakukan pendaftaran Judul,pendaftaran seminar dan pendaftaran sidang tugas akhir.

\section{Activity Diagram}

Terdapat 3 buah Aktivitas utama dalam pengelolaan data Tugas akhir pada Jurusan Teknik Informatika yaitu Pengajuan Judul, Pengajuan Seminar dan Pengajuan Sidang, Berikut Activity Diagram proses utama:

a. Activity Diagram Pengajuan Judul

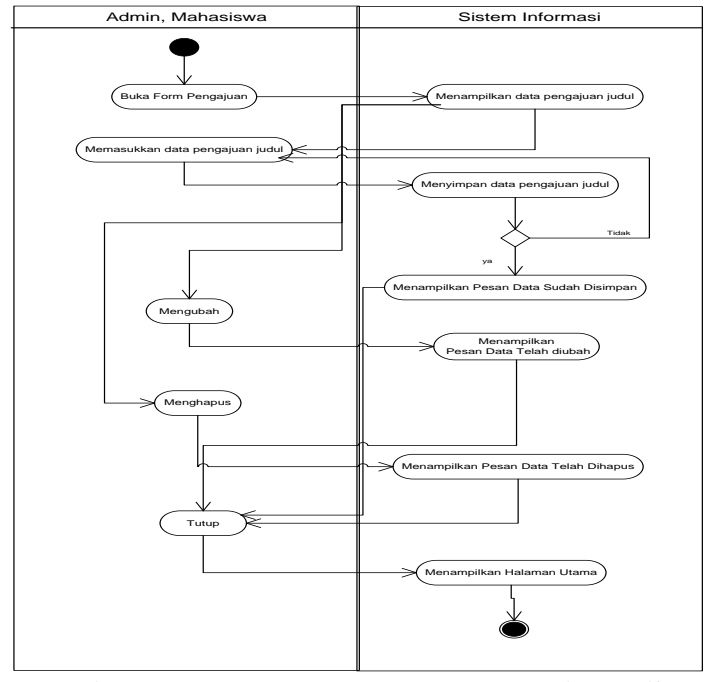

Gambar 3. Activity Diagram Input dan edit Data Judul

Pada Gambar 3. activity diagram data pengajuan judul ini setelah admin dan mahasiswa dapat melakukan proses login dan membuka form pengajuan judul. Setelah itu user memasukkan data pengajuan judul secara benar dan menyimpan data pengajuan judul tersebut. Selanjutnya jika user ingin mengubah data pengajuan judul maka setelah data yang diubah selesai maka akan menampilkan pesan bahwa data sudah tersimpan. Dan user dapat melakukan proses hapus. Setelah itu user menutup form input pengajuan judul dan sistem akan menampilkan menu utama kembali.

\section{b. Activity Diagram Pengajuan Seminar}

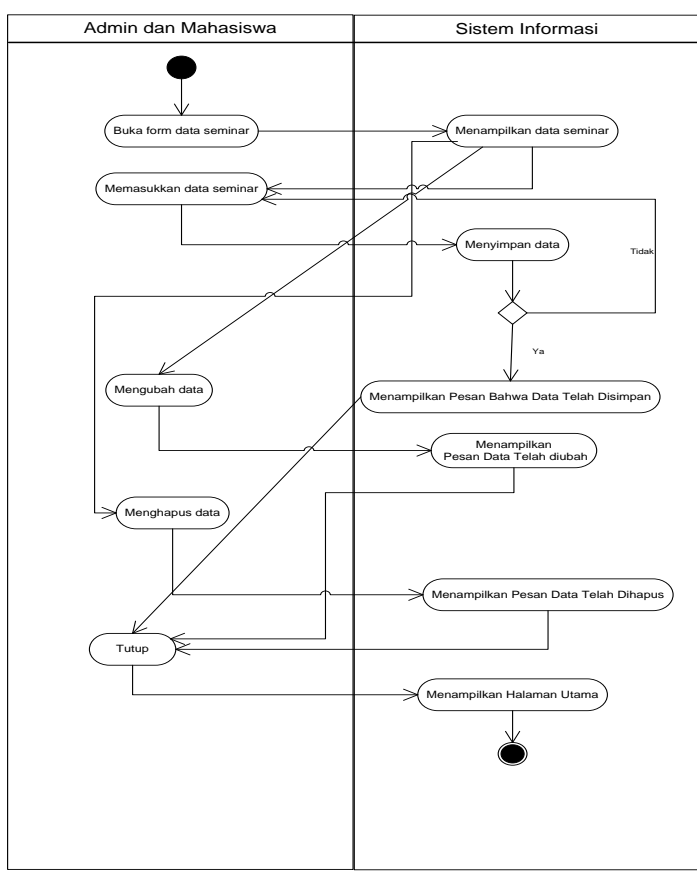

Gambar 4. Activity Diagram Input dan edit Data Seminar

Pada Gambar 4 activity diagram data seminar ini setelah admin melakukan proses login berhasil maka admin membuka form input seminar. Setelah itu admin memasukkan data seminar secara benar dan menyimpan 
data seminar tersebut. Selanjutnya jika admin ingin mengubah data maka setelah data yang diubah selesai maka akan menampilkan pesan bahwa data sudah tersimpan. Dan admin dapat melakukan proses hapus. Setelah itu admin menutup form data seminar setelah itu sistem akan menampilkan menu utama kembali.

c. Activity Diagram Pengajuan Sidang

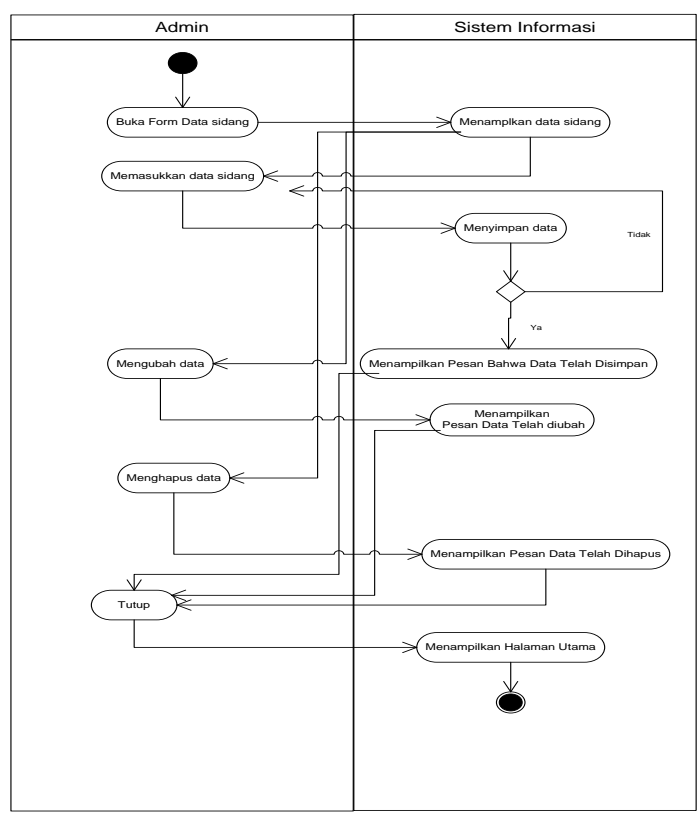

Gambar 5. Activity Diagram Input dan edit Data Sidang

Pada Gambar 5 activity diagram input dan edit data sidang, setelah admin melakukan proses login berhasil maka admin membuka form sidang. Setelah itu admin memasukkan data sidang secara benar dan menyimpan data sidang tersebut. Selanjutnya jika admin ingin mengubah data sidang maka setelah data yang diubah selesai maka akan menampilkan pesan bahwa data sudah tersimpan. Dan admin dapat melakukan proses hapus. Setelah itu admin menutup form sidang setelah itu sistem akan menampilkan menu utama kembali.

d. Class Diagram

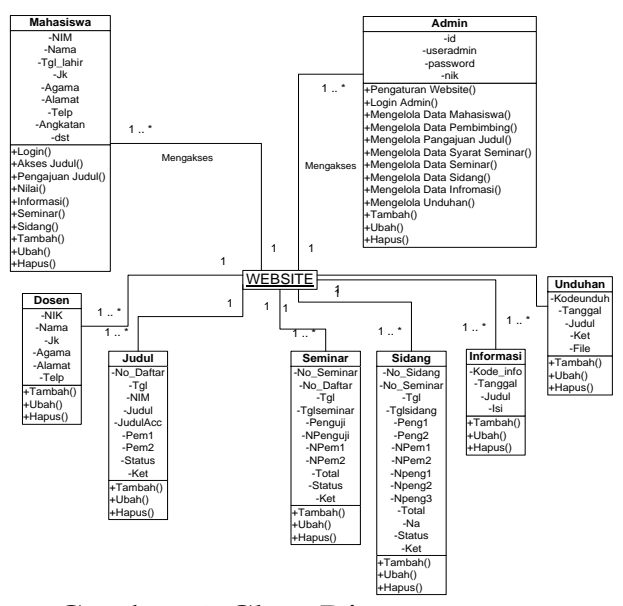

Gambar 6. Class Diagram

Terdapat delapan buah entitas class dalam sistem pengelolaan data tugas akhir jurusan Teknik Informatika STMIK Palangkaraya yaitu entitas Admin, Mahasiswa, Dosen, Judul, Seminar, Sidang, Informasi dan Unduhan. Entity Class tersebut mengambarkan Model Attribut dan Behavior dari setiap object yang terlibat pada sistem yang kemudian sebagai referensi untuk membantu memodelkan diagram ER untuk diimplementasikan ke dalam Desain Basis Data Relasional. e. Sequence Diagram 
Sequence diagram digunakan untuk menggambarkan scenario atau rangkaian langkah-langkah yang dilakukan sebagai sebuah respon dari suatu kejadian untuk menghasilkan output tertentu. Berikut beberapa sequence diagram yang telah di susun :

1) Sequence Diagram Login

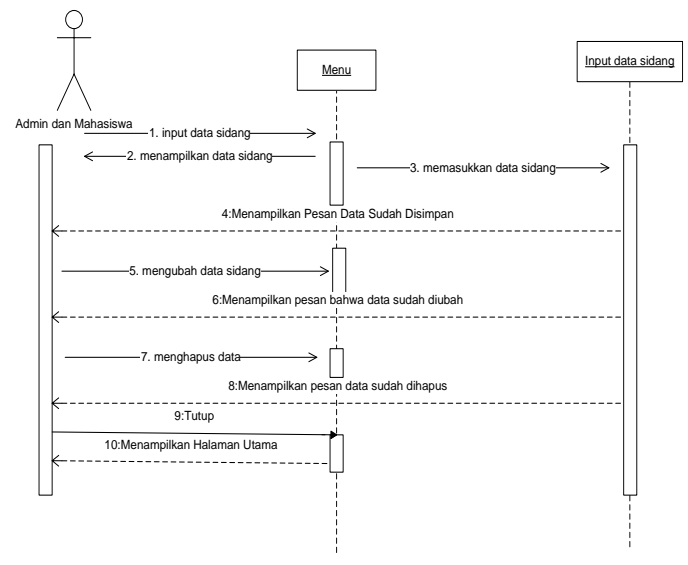

Gambar 7. Sequence Diagram Login

Pada Gambar 7 Sequence diagram login terdapat 1 buah actor user dan 2 objek, yaitu: main dan login. Pertama-tama user akan masuk ke layar main dengan memasukkan Username dan Password. Dari Layar login, user akan memasukkan Username dan Password. Dengan memasukkan username dan password digunakan untuk melakukan validasi apakah user seorang operator atau mahasiswa. Validasi ini bertujuan untuk membuka menu halaman utama tiap user .

2) Sequence Diagram Input Data Judul

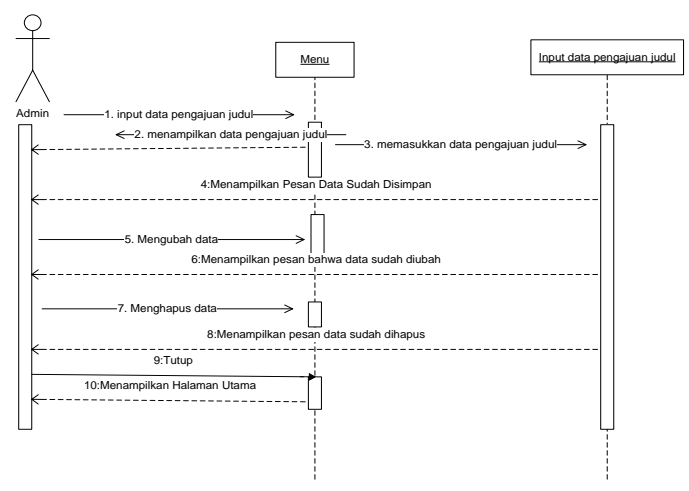

Gambar 8. Sequence Diagram Input Data Judul

Pada Gambar 8 Sequence Diagram Input Data Pengajuan Judul terdapat 1 admin dan 2 objek, yaitu: menu dan input data pengajuan judul. Pertama-tama admin akan masuk ke layar menu utama. Dari input pengajuan judul, admin akan melakukan kelola pengajuan judul. Dengan memasukkan pengajuan judul tersebut. Admin memilih simpan, dan data pengajuan judul sudah tersimpan. Jika Admin akan mengubah salah satu dari data pengajuan judul. Admin dapat memilih button edit. Sistem akan menyimpan data yang sudah diedit. Jika admin menghapus data pengajuan judul maka sistem akan menghapus data pengajuan judul. 
Pada contoh Gambar 10

3) Sequence Diagram Data Seminar

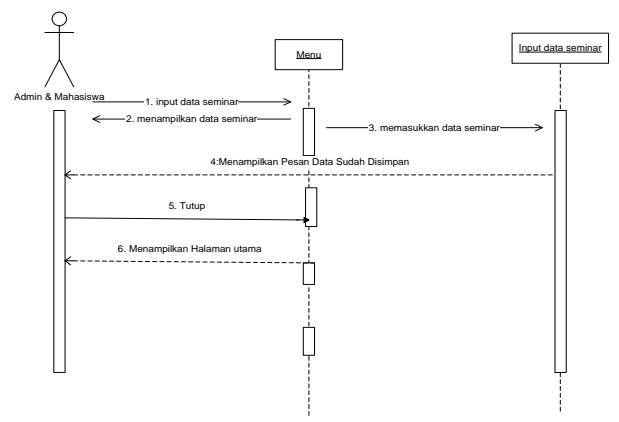

Gambar 9. Sequence Diagram Input Data Seminar

Pada contoh Gambar 9 sequence diagram input data seminar terdapat 1 admin dan 2 objek, yaitu: menu dan input data seminar. Pertama-tama admin akan masuk ke layar menu utama. Dari input data seminar, admin akan melakukan kelola seminar. Admin memilih simpan,dan data seminar sudah tersimpan.

4) Sequence Diagram Data Sidang

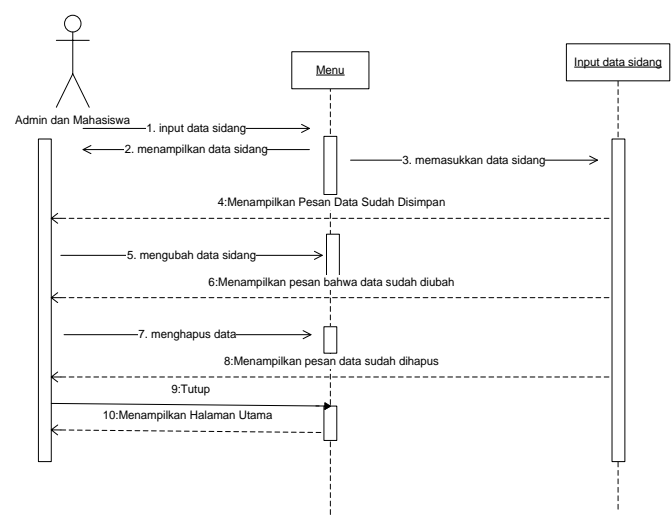

Gambar 10. Sequence Diagram Input Data Sidang
Sequence Diagram input data sidang terdapat 1 admin dan 2 objek, yaitu: menu dan input data sidang. Pertamatama admin akan masuk ke layar menu utama. Dari input data sidang, admin akan melakukan kelola data sidang. Dengan memasukkan data sidang tersebut. Admin memilih simpan,dan data sidang sudah tersimpan. Jika Admin akan mengubah salah satu dari data sidang. Admin dapat memilih tombol edit. Sistem akan menyimpan data yang sudah diedit. Jika admin menghapus data sidang maka sistem akan menghapus data sidang.

\section{f. ER-Diagram}

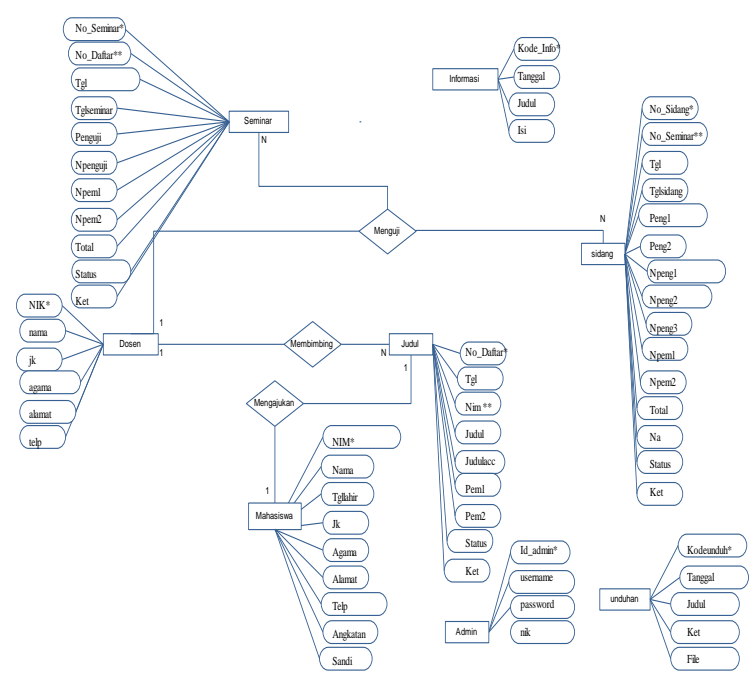

Gambar 11. ER Diagram

Pada Gambar 11 terdapat 8 (delapan) entitas dimana masing-masing entitas saling berhubungan kecuali entitas unduhan, admin dan informasi 
hal ini karena entitas tersebut tidak memerlukan entitas lain dalam pengolahan datanya.

Untuk entitas sidang berelasi satu ke banyak dengan entitas dosen karena dosen dimungkinkan untuk menguji banyak sidang. Untuk entitas lain berelasi satu kesatu dengan entitas lain hal ini dikarenakan setiap entitas saling berelasi dengan entitas lain dalam satu proses misalnya mahasiswa dengan judul.

Hasil dari Aplikasi Web Pengelolaan data Tugas Akhir pada Jurusan Teknik Informatika STMIK Palangkaraya terdiri dari beberapa Output Sistem :

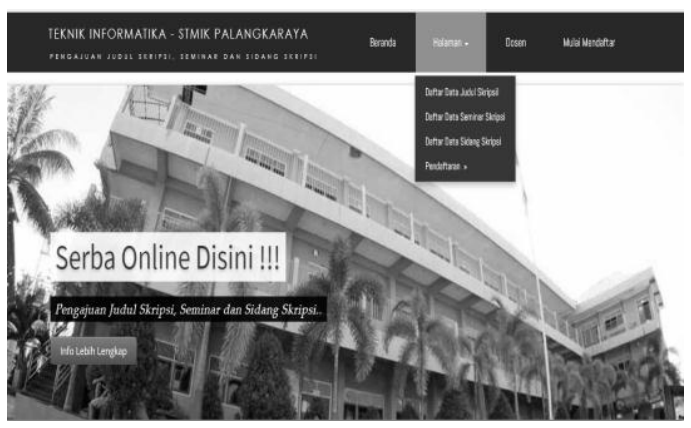

Gambar 12. Halaman Utama

Pada Gambar 12 halaman utama aplikasi web terdapat menu untuk user umum dapat melihat beberapa informasi seperti syarat-syarat pengajuan judul,seminar dan sidang tugas akhir, data daftar judul, jadwal seminar dan jadwal sidang serta daftar dosen pembimbing di jurusan teknik informatika STMIK Palangkaraya.
Untuk melakukan pengajuan judul,jadwal seminar dan jadwal sidang tugas akhir mahasiwa harus memiliki akun untuk dapat login ke sistem.

Data yang masuk akan diproses oleh operator di bagian halaman administrator seperti yang ditunjukkan pada Gambar 13 di bawah ini :

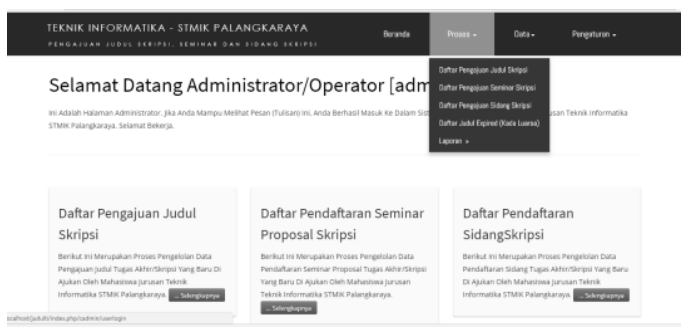

Gambar 13.Halaman Dashboard Operator

Pada Gambar 13 ada beberapa layanan yang dapat digunakan oleh seorang operator yaitu proses pengajuan judul,proses pengajuan jadwal seminar, proses pengajuan jadwal sidang tugas akhir, proses daftar judul kadaluarsa(expired) dan cetak laporan (informasi) . Pada proses pengajuan judul tugas akhir, operator akan merekap daftar pengajuan judul untuk di serahkan ke tim pembahas judul tugas akhir di jurusan teknik informatika,setelah daftar judul di nilai maka operator akan mengupdate status daftar judul yang di ajukan mahasiswa dengan memilih status judul apakah di pending,diterima, atau di tolak. Setelah diproses oleh operator daftar judul yang 
diajukan akan otomatis dapat di lihat di halaman utama aplikasi web pengelolaan Tugas akhir pada jurusan Teknik Informatika STMIK Palangkaraya seperti yang ditunjukkan pada Gambar 14, Gambar 15 dan Gambar 16.

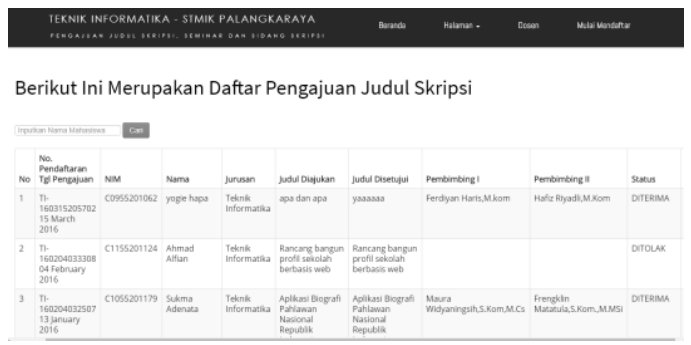

Gambar 14. Informasi Pengajuan Judul Tugas Akhir

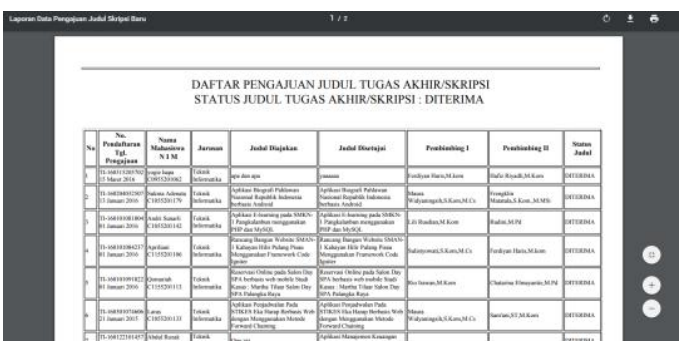

Gambar 15. Laporan Daftar Judul yang di terima

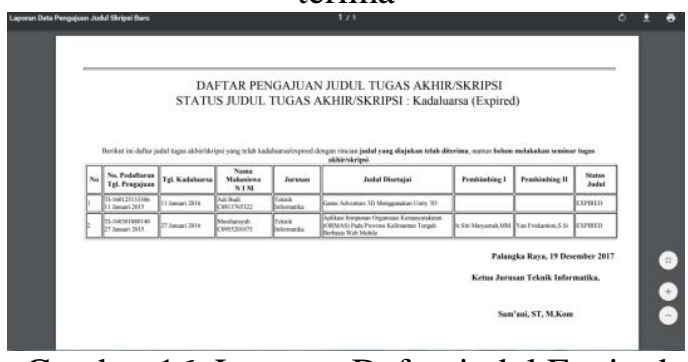

Gambar 16. Laporan Daftar judul Expired

\section{KESIMPULAN}

Dari uraian keseluruhan yang telah dikemukakan mulai dari proses analisis hingga implementasi sistem dapat diambil kesimpulan yaitu Aplikasi Web Pengelolaan Tugas akhir pada jurusan teknik Informatika STMIK Palangkaraya berhasil dibangun dan dapat memberi kemudahan kepada mahasiswa dan pihak jurusan dalam melakukan pengelolaan tugas akhir dalam mengajukan judul, jadwal seminar, dan jadwal ujian tugas akhir kapan saja dan dimana saja sepanjang terkoneksi internet sehingga layanan informasi terkait tugas akhir mahasiswa menjadi lebih efektif dan optimal.

\section{SARAN}

Aplikasi Web Pengelolaan Tugas Akhir Pada Jurusan Teknik Informatika STMIK Palangkaraya masih banyak kekurangan fasilitas seperti notifikasi Jadwal Seminar dan Ujian kepada Mahasiswa dan Dosen Penguji, serta fasilitas untuk penilaian yang langsung diinputkan oleh dosen penguji baik pada saat seminar maupun sidang tugas akhir agar informasi nilai semakin cepat dan mengurangi beban kerja operator jurusan.

\section{DAFTAR PUSTAKA}

Abdul Kadir. 2003. Pengenalan Sistem Informasi. Yogyakarta: Andi Offset

Fathansyah. 2005 . Sistem Basis Data. Bandung: Informatika.

Jogiyanto H. M. 2005. Analisis \& Desain Sistem Informasi : Pendekatan Terstruktur Teori 
dan Praktik Aplikasi Bisnis. Yogyakarta: Andi.

Kandaga. T dan Felix. V. 2011 Pembuatan Aplikasi Pengelolaan Tugas Akhir Online Berbasis Web Studi Kasus Jurusan Teknik Informatika UKM. Jurnal Sistem Informasi. 6: (2): 185-197

Nugroho, A. 2010. Rekayasa Perangkat Lunak Berorientasi Objek dengan Metode USDP. Yogyakarta: ANDI OFFSET

Martin, .2005. UML DISTILLED. 3th Ed. Panduan Singkat Bahasa Pemodelan Objek Standar. Yogyakarta: Andi Offset.

Pressman, S. R. 2010. Rekayasa Perangkat Lunak, Yogyakarta: ANDI.

Primasetya, G. 2013. Aplikasi Pengajuan Skripsi Mahasiswa Jurusan Sistem Informasi Universitas Gunadarma Berbasis Android, 1-13

Simarmata, J. 2010. Rekayasa Web, Yogyakarta: Andi 